PERBEDAAN TINGKAT KECEMASAN PADA
PASIEN DIABETES MELITUS DENGAN
NEUROPATI PERIFER YANG DIBERIKAN
INTERVENSI TENS DAN INTERVENSI NAFAS
DALAM SAAT DILAKUKAN PERAWATAN
ULKUS KAKI DIABETIK DI RSUD KOTA
YOGYAKARTA

PERBEDAAN TINGKAT KECEMASAN PADA PASIEN DIABETES MELITUS DENGAN NEUROPATI PERIFER YANG DIBERIKAN DALAM SAAT DILAKUKAN PERAWATAN YOGYAKARTA

\author{
Satriya Pranata ${ }^{1}$ \\ ${ }^{1}$ Program Pendidikan S1 Keperawatan Universitas Muhammadiyah Semarang, Jl Kedung Mundu Raya \\ No. 18, Semarang 50273
}

\title{
ABSTRAK
}

Pendahuluan: Intervensi yang rutin dilakukan pada ulkus kaki diabetik adalah perawatan luka. Saat seorang perawat melakukan perawatan luka pasien sering mengeluhkan nyeri, bila nyeri tidak teratasi akan mengakibatkan munculnya perasaan ansietas. Selama ini intervensi yang rutin dilakukan adalah nafas dalam, itupun hanya untuk menurunkan nyeri karena diharapkan dengan penurunan nyeri akan diikuti juga oleh penurunan ansietas. Intervensi nafas dalam belum mampu menurunkan nyeri secara cepat pada skala sedang apalagi skala tinggi sehingga perlu dipikirkan alternatif intervensi lainnya. Intervensi pembanding yang ditawarkan adalah TENS. Penelitian ini ingin melihat perbedaan intervensi TENS dan nafas dalam terhadap tingkat ansietas pada pasien DM dengan Neuropati Perifer yang dilakukan perawatan ulkus kaki diabetik. Metodologi : Penelitian ini menggunakan metode RCT pada 28 responden yang dibagi menjadi 14 kelompok intervensi dan 14 kelompok kontrol. Ansietas responden dikaji menggunakan tools Hamilton rating Scale of Anxiety sebelum dan sesudah dilakukan intervensi TENS dan nafas dalam. TENS diberikan selama 15 menit dengan frekuensi $100 \mathrm{~Hz}$ dan nafas dalam diberikan sampai intervensi perawatan luka selesai dilakukan. Hasil : ada beda rata-rata yang signifikan tingkat ansietas antara yang menggunakan TENS dengan nafas dalam pada kelompok intervensi dan kelompok kontrol dengan nilai $\mathrm{P}<0.05$. TENS mampu menurunkan tingkat ansietas dengan nilai $P$ 0.000, nafas dalam mampu menurunkan tingkat ansietas dengan nilai $P$ 0.006. Diskusi : Responden mengaku sulit mengalami relaksasi maksimal ketika dilakukan perawatan luka, kondisi ini berkaitan dengan posisi nyaman responden. Saat dilakukan perawatan luka, responden tidak bisa relaks secara maksimal karena sering kali kaki yang mengalami ulkus harus di ganjal dengan bantal untuk memaksimalkan perawatan. Pemberian TENS dengan frekuensi $100 \mathrm{~Hz}$ sesuai dengan bioelektrik tubuh. pasien yang mendapatkan intervensi TENS dapat menjadi lebih relaks dengan penegeluaran hormone endorphin dan penurunan nyeri karena listrik yang dihasilkan memblok impuls nyeri pada serabut saraf.

Kata kunci : Transcutaneous Electrical Nerve Stimulation, Ansietas, Nafas Dalam, Diabetes Melitus

\section{DIFFERENT PAIN LEVEL OF DIABETES MELLITUS PATIENTS WITH PERIPHERAL NEUROPATHY WHO HAVE BEEN GIVEN TENS AND DEEP BREATHING INTERVENTIONS IN DIABETIC FOOT ULCER TREATMENT IN YOGYAKARTA GENERAL HOSPITAL}


Introduction : Regular intervention of diabetic foot ulcers is wound care. Patients often complain of pain when nurse performs wound care. If the pain is not resolved it will result in anxiety feeling. A routine intervention conducted so far is intra-breath in intervention to reduce pain, as it is expected by reducing the pain it will be followed by a decrease of patients' anxiety. Intra-breath intervention has not been able to reduce pain quickly on a moderate scale, especially high-scale so it is necessary to find out other alternative interventions. The available comparative intervention is TENS. The purpose of this study is to know the difference between intrabreath and TENS intervention in the level of anxiety in diabetic patients with peripheral neuropathy in diabetic foot ulcer treatment. Method: This study used RCT method on 28 respondents divided into 14 intervention groups and 14 control groups. The anxiety of respondents was assessed using Hamilton Scale of Anxiety tools before and after conductin TENS intervention and intra-breath. TENS intervention was given for 15 minutes at a frequency of $100 \mathrm{~Hz}$ and intra-breath was given until the wound care intervention was completed. Result : The results showed that there was significant average difference of anxiety level between the use of TENS intervention and the use of intra-breath intervention in intervention group and the control group with value of $P<0.05$. TENS can reduce the level of anxiety with the value of $P 0.000$, while intra -breath is able to lower the level of anxiety with the value of $P$ 0.006. Discussion : The respondents admitted the difficulty of experience maximum relaxation when wound care is done, this condition is related to the comfortable position of respondents. When wound care is done, the respondents can not relax maximaly because many of the foot that has ulcers should be padded with a pillow to maximize the treatment. Provision of TENS with a frecuency of $100 \mathrm{~Hz}$ is corresponding to the body's bioelectricity, the patients that receive TENS intervention may become more rrelaxed with endorphine hormone release and decreasing of pain because the electricity blocks pain implans in the neural tube.

Keywords : Transcutaneous Electrical Nerve Stimulation, Anxiety, Deep Breathing, Diabetes Mellitus

Corresponding Author :

Satriya Pranata ${ }^{1}$, Nursing Undergraduate Program, Faculty of Health and Nursing, Muhammadiyah Semarang University, Kedungmundu Raya Street No. 18 Semarang 50273. E-mail : satriyapranatapranata@yahoo.co.id

\section{PENDAHULUAN}

Diabetes melitus (DM) adalah suatu keadaan peningkatan kadar glukosa darah yang disertai oleh kelainan metabolik akibat gangguan hormonal yang menimbulkan komplikasi menahun pada berbagai organ target (Soegondo, 2009). Data International Diabetes Federation (IDF) tahun 2014 menunjukkan bahwa 1 dari 12 orang di dunia menderita DM. Total penderita DM di seluruh dunia berjumlah 387 juta jiwa (8,3\%), jumlah penderita DM yang meninggal di tahun 2014 mencapai angka 4,9 juta jiwa (IDF, 2014). Jumlah penderita DM di Indonesia pada tahun 2014 adalah 9,1 juta jiwa (5,81\%). DM yang tidak terdiagnosis berjumlah 4,8 juta (5,27\%), penderita yang meninggal akibat DM berjumlah 175.836 jiwa (1.9\%), diperkirakan jumlah penduduk Indonesia yang menderita DM di tahun 2035 mencapai angka 14,1 juta (IDF, 2014) .

Peningkatan jumlah penderita DM setiap tahun menuntut profesi perawat untuk terus meningkatkan pelayanan kesehatan dimasa mendatang (Potter, PA \& Perry, 2005). Program yang sudah dijalankan oleh pemerintah dan tenaga kesehatan di rumah sakit untuk meningkatkan pelayanan tersebut 
adalah dengan membentuk komunitas DM, pembuatan poli khusus DM, pengambilan langkah promotif dan preventif melalui pengelolaan non farmakologis, perencanaan makan, penyuluhan dan kegiatan jasmani. Saat langkah promotif dan preventif belum mampu mengendalikan glukosa darah penderita DM, program selanjutnya yang dilakukan rumah sakit adalah dengan pengelolaan farmakologis (Soegondo, 2009; Waspadji, 2009).

Pelaksanaan program farmakologis hingga saat ini belum mampu mengatasi masalah pada penderita DM secara utuh. Pasien dengan penyakit DM masih memiliki resiko tinggi mengalami berbagai macam komplikasi makro dan mikro. Komplikasi makro yang dapat terjadi adalah gagal jantung, gagal ginjal dan stroke, sedangkan untuk komplikasi mikro seperti retinopati diabetik, nefropati diabetik hingga neuropati diabetik perifer (Soegondo, 2009; Waspadji, 2009).

Neuropati diabetik perifer adalah salah satu komplikasi pada penyakit diabetes melitus dimana terjadi gangguan fungsi pada sistim saraf tepi dikarenakan oleh berbagai faktor seperti metabolik, trauma, penyakit defisiensi, gangguan imunologis dan genetic (Soegondo, 2009; Waspadji, 2009). Neuropati diabetik perifer merupakan kondisi kerusakan saraf akibat dari gangguan metabolisme pengaturan kadar glukosa di dalam darah (Lemone, P \& Burke, 2008; Lewis, 2005; Silbernagl, S. \& Lang, 2007; Soegondo, 2009). Data menunjukkan bahwa 60-70 \% penderita DM mengalami neuropati diabetik perifer dan ulkus DM (Lemone, P \& Burke, 2008). Gangguan neuropati diabetik perifer berakibat pada hambatan signal rangsangan komunikasi dalam tubuh, akibatnya pasien mengalami gangguan sensasi dan kering pada kulit karena kelenjar keringat dibawah kulit berkurang. Gangguan sensasi akan menyebabkan transmisi nyeri ke otak untuk menyadarkan penderita adanya bahaya di kaki seperti tertusuk paku atau terkena obyek panas menjadi hilang, kondisi ini yang mengakibatkan kejadian ulkus diabetik dibagian kaki sulit untuk dihindari (Brunner and Suddarth, 2001; Soegondo, 2009).

Intervensi yang rutin dilakukan pada ulkus kaki diabetik adalah perawatan luka. Saat seorang perawat melakukan perawatan luka pasien sering mengeluhkan nyeri, bila nyeri tidak teratasi akan mengakibatkan munculnya perasaan ansietas yang dirasakan oleh pasien ketika dilakukan perawatan (Kristianto, 2010).

Ansietas merupakan perasaan tidak nyaman yang belum jelas penyebabnya serta tidak didukung oleh situasi, bila ansietas tidak diatasi akan mengakibatkan meningkatkan norepinephrine diikuti pula oleh peningkatan dopamine, kortisol serta serotonin (Videbeck, 2011). Peningkatan hormon kortisol juga berkibat pada meningkatnya konversi asam amino, laktat dan piruvat di hati menjadi glukosa melalui proses glukoneogenesis kemudian akan diikuti oleh peningkatan glukosa darah, tentu kondisi 
merupakan kondisi yang tidak diharapkan pada pasien yang mengalami ulkus diabetic dengan neuropati perifer (Brunner and Suddarth, 2001).

Selama ini belum ada intervensi khusus yang dilakukan untuk mengatasi ansietas di rumah sakit terutama untuk menurunkan ansietas saat dilakukan perawatan luka. Intervensi yang rutin dilakukan hanya nafas dalam, itupun hanya untuk menurunkan nyeri karena diharapkan dengan penurunan nyeri akan diikuti juga oleh penurunan ansietas pasien. Intervensi nafas dalam belum mampu menurunkan nyeri secara cepat pada skala sedang apalagi skala tinggi sehingga perlu dipikirkan alternatif intervensi lainnya. Salah satu intervensi pembanding yang ditawarkan adalah intervensi TENS karena intervensi ini sudah terbukti dapat menurunkan nyeri skala ringan hingga sedang pada pasien diabetes mellitus dengan neuropati perifer saat dilakukan perawatan luka (Pranata, Hs, \& Sujianto, 2016). Dengan berkurangnya nyeri pasien, akan diikuti juga oleh penurunan ansietas (Sharma et al., 2015).

Melihat pentingnya mengatasi ansietas serta belum adanya penelitian serupa, maka penelitian perbandingan intervensi TENS dan nafas dalam untuk menurunkan ansietas pada pasien DM dengan neuropati perifer perlu dilakukan. Tujuan dari penelitian ini adalah ingin melihat perbedaan tingkat kecemasan pada pasien DM dengan neuropati perifer yang mendapatkan intervensi TENS dan nafas dalam saat dilakukan perawatan luka.

\section{METODE}

Metode penelitian yang digunakan adalah Random Control Trial with single blind. Penelitian ini dilakukan sejak bulan Mei hingga Juli 2016 di RSUD Kota Yogyakarta. Jumlah responden dalam penelitian adalah 28 responden dengan 14 kelompok intervensi dan 14 kelompok kontrol. Dalam penelitian ini sampel yang digunakan adalah sampel yang memenuhi kriteria inklusi dan sampel yang tidak terekslusi. Kriteria inklusi pada penelitian ini adalah: Tidak mengkonsumsi obat psikotik saat dilakukan penelitian, tidak sedang mengalami penurunan kesadaran, mengalami ansietas sebelum dilakukan perawatan luka, tidak sedang mendapatkan obat anti nyeri sebelum dilakukan intervensi TENS, pasien dengan ulkus DM pada ekstremitas bawah, ulkus DM stadium 1 dan 2. Kriteria ekslusi pada penelitian ini: Pasien DM yang memiliki penyakit lain seperti epilepsy, pasien tidak terpasang elektroda yang berhubungan dengan monitoring jantung.

Alat penelitian yang digunakan adalah kuesioner karakteristik responden, standar operasional prosedur nafas dalam, TENS sebagai intervensi tambahan saat dilakukan perawatan ulkus kaki diabetikum, Hamilton Rating Scale of anxiety untuk mengukur tingkat ansietas, dan standar prosedur perawatan luka. Nama product TENS adalah Beurer Digital TENS dengan rentang frekuensi 1-250 Hz. 
Sebelum penelitian dilaksanakan, peneliti mengajukan permohonan tertulis kepada direktur RSUD Kota Yogyakarta. Selanjutnya melakukan sosialisasi dan menjelaskan tentang maksud, tujuan dan prosedur penelitian pada kepala ruang, staf perawat dan dokter penanggung jawab pasien. Peneliti memilih pasien yang terdiagnosa diabetes mellitus dengan neuropati perifer berdasarkan data rekam medis dan penentuan neuropati perifer menggunakan tes Doulour Neuropathi 4 (DN4). Setelah pasien masuk dalam kriteria inklusi, peneliti kemudian meminta kesediaan calon responden untuk berpartisipasi setelah mendapatkan penjelasan tentang maksud, tujuan, manfaat, prosedur penelitian, serta hak dan kewajiban menjadi responden. Bagi responden yang bersedia, peneliti selanjutnya meminta calon responden menandatangani lembar inform concern. Selajutnya responden di random untuk menentukan apakah responden masuk kelompok intervensi atau kelompok kontrol.

Kelompok intervensi mendapatkan intervensi TENS selama 15 menit dan Kelompok control mendapatkan intervensi nafas kemudian diukur tingkat ansietasnya. Elektroda alat TENS diletakkan dijalur yang dilewati oleh saraf nyeri sekitar luka dengan frekuensi $100 \mathrm{~Hz}$. Kelompok control diberikan intervensi nafas dalam sampai selesai perawatan luka selama 15 menit. Tingkat ansietas responden pada kelompok intervensi atau kelompok kontrol diukur dengan tools Hamilton Rating Scale of anxiety. Pengukuran ansietas dilakukan pada pre dan post intervensi.

\section{HASIL}

Tabel 1. Distribusi frekuensi tingkat ansietas responden sebelum dan setelah intervensi

\begin{tabular}{lllll}
\hline & TENS & & Nafas Dalam \\
\cline { 2 - 5 } & Pre (\%) & Post (\%) & Pre (\%) & Post (\%) \\
\hline Tidak ada kecemasan & $0(0 \%)$ & $10(71,42 \%)$ & $0(0 \%)$ & 4 \\
Kecemasan ringan & $11(78,57 \%)$ & $4(28,58 \%)$ & $11(78,57 \%)$ & $(16,8 \%)$ \\
Kecemasan sedang & $2(14,28 \%)$ & & $2(14,28 \%)$ & 10 \\
Kecemasan berat & $1(7,15 \%)$ & & $1(7,15 \%)$ & $(14,4 \%)$ \\
\hline
\end{tabular}

Tabel 2. Hasil analisis uji beda tingkat ansietas pada kelompok yang mendapatkan TENS dan nafas dalam

\begin{tabular}{llllc}
\hline Variable & $\begin{array}{l}\text { Levene Test fo Equality of } \\
\text { Variance }\end{array}$ & $\mathrm{t}$ & $\mathrm{df}$ & Pvalue \\
\hline $\begin{array}{l}\text { Tingkat ansietas sebelum intervensi pada } \\
\text { kelompok TENS dan kelompok nafas dalam }\end{array}$ & 1.000 & 0.000 & 26 & 1.000 \\
\hline $\begin{array}{l}\text { Tingkat ansietas setelah intervensi pada } \\
\text { kelompok TENS dan kelompok nafas dalam }\end{array}$ & 1.000 & 2.419 & 26 & 0.023 \\
\hline
\end{tabular}


Tabel 3. Hasil analisis uji pengaruh intervensi terhadap tingkat ansietas sebelum dan sesudah intervensi

\begin{tabular}{lllllll}
\hline Variable & Kelompok & Mean & SD & $\mathrm{N}$ & $\mathrm{Cl} 95 \%$ & $\mathrm{p}$-value \\
\hline \multirow{2}{*}{ Tingkat ansietas } & TENS & 1.00 & 0.39 & 14 & $0.773-1.226$ & 0.000 \\
\cline { 2 - 7 } & Nafas Dalam & 0.57 & 0.64 & 14 & $0.198-0.944$ & 0.006 \\
\hline
\end{tabular}

Tabel 6. Perhitungan Delta antara kelompok TENS dengan nafas dalam

\begin{tabular}{lllll}
\hline & Kelompok & Mean & $\mathrm{N}$ & $\mathrm{p}$-value delta ansietas \\
\hline \multirow{2}{*}{ Gain Tingkat ansietas } & TENS & -1.0000 & 14 & 0.034 \\
\cline { 2 - 5 } & Nafas Dalam & -0.5714 & 14 & \\
\hline
\end{tabular}

\section{PEMBAHASAN}

Rata-rata tingkat ansietas responden pada kelompok TENS dan kelompok dengan perlakuan nafas dalam sebelum diberikan intervensi masing-masing berjumlah 11 responden cemas ringan (78,57\%), 2 responden cemas sedang $(14,28 \%)$ dan 1 responden cemas berat (7,15\%). Homogenitas pada kedua kelompok sebelum dilakukan intervensi sama dikarenakan ada perlakuan randomisasi dengan ketat, jenis randomisasi yang dilakukan adalah random blok. Setelah mendapatkan perlakukan TENS, tingkat kecemasan responden berubah menjadi 10 responden tidak ada kecemasan (71,42\%) dan 4 responden mengalami kecemasan ringan (28,58\%). Setelah mendapatkan perlakuan nafas dalam, tingkat kecemasan responden berubah menjadi 4 responden tidak ada kecemasan (28,58\%) dan 10 responden mengalami kecemasan ringan (71,42\%).

Responden mengaku bahwa ansietas yang dialami karena nyeri saat dilakukan perawatan luka, perawatan di rumah sakit dalam waktu yang cukup sering serta harus jauh dari keluarga dan tempat tinggalnya. Sebagian responden ada yang mengaku cemas karena akan menjalani operasi diakibatkan oleh neuropati yang dialami. Hasil penelitian ini sejalan dengan hasil penelitian yang dilakukan oleh Wirnata (2009) yang menyatakan bahwa cemas pada pasien muncul dikarenakan oleh penolakan dan penerimaan interpersonal, cemas juga berhubungan dengan perkembangan trauma seperti perpisahan dari lingkungan keluarga atau rumah serta kehilangan yang menimbulkan kelemahan. Hasil penelitian ini juga didukung oleh penelitian yang dilakukan oleh Sharma (2015) yang menyatakan bahwa ada korelasi yang kuat antara tingkat nyeri dengan tingkat kecemasan, semakin seseorang merasakan sensasi nyeri maka kecemasan juga akan semakin meningkat.

Hasil perhitungan statistik menunjukkan bahwa tidak terdapat perbedaan tingkat ansietas pada kelompok TENS dan kelompok nafas dalam sebelum diberikan perlakuan dengan nilai $P 1.000(P$ value $>0.05$ ). Setelah dilakukan perlakuan terdapat perbedaan tingkat ansietas yang signifikan dengan nilai P 0.023 ( $p$ value $<0.05$ ). Maka dapat disimpulkan bahwa ada perbedaan yang signifikan 
tingkat ansietas setelah diberikan perlakuan baik perlakuan berupa TENS atau perlakuan berupa nafas dalam.

Hasil perhitungan statistik menunjukkan bahwa intervensi TENS efektif menurunkan ansietas pasien dengan nilai P 0.000 ( $p$ value $<0.05$ ). Sinyal dari TENS ini berfungsi untuk mengganggu sinyal nyeri yang mempengaruhi saraf-saraf dan memutus sinyal nyeri tersebut sehingga pasien merasakan nyerinya berkurang. Selain itu, stimulasi listrik saraf dapat membantu tubuh untuk memproduksi obat penghilang rasa sakit alami yang disebut endorfin, yang dapat menghalangi persepsi nyeri. TENS menstimulasi saraf melalui listrik dimana frekuensi impuls yang dihantarkan sebanding dengan bioelectricity alami tubuh, dengan cara ini transmisi nyeri oleh serabut saraf terhambat kemudian aliran listrik menghilangkan rasa sakit, zat endorphin keluar dan aktif selanjutnya akan diikuti oleh lancarnya aliran darah melalui zona tubuh sehingga relaksasi meningkat dan ansietas menurun. Intensitas listrik yang diberikan maksimal adalah $100 \mathrm{~Hz}$, kondisi ini dikarenakan bila diberikan pada intensitas yang terlalu tinggi akan mengakibatkan luka bakar (Pranata et al., 2016). Elektroda yang diberikan terdiri dari 4 elektroda yang membawa arus listrik ke bagian ekstremitas responden. Setiap elektroda harus ditempatkan pada jalur-jalur inervasi saraf yang tepat, akibat bila tidak ditempatkan pada jalur inervasi yang tepat maka aktifitas listrik tidak dapat bekerja dengan baik dalam memblok saraf nyeri untuk menghasilkan perasaan nyaman hingga akhirnya menurunkan tingkat ansietas. Jalur inervasi tersebut adalah jalur L4, L5 dan S1. Jalur inervasi ini akan berakhir di plantar kaki dimana lokasi ulkus DM paling banyak terjadi. Berikut merupakan gambaran dari jalur inervasi tersebut:
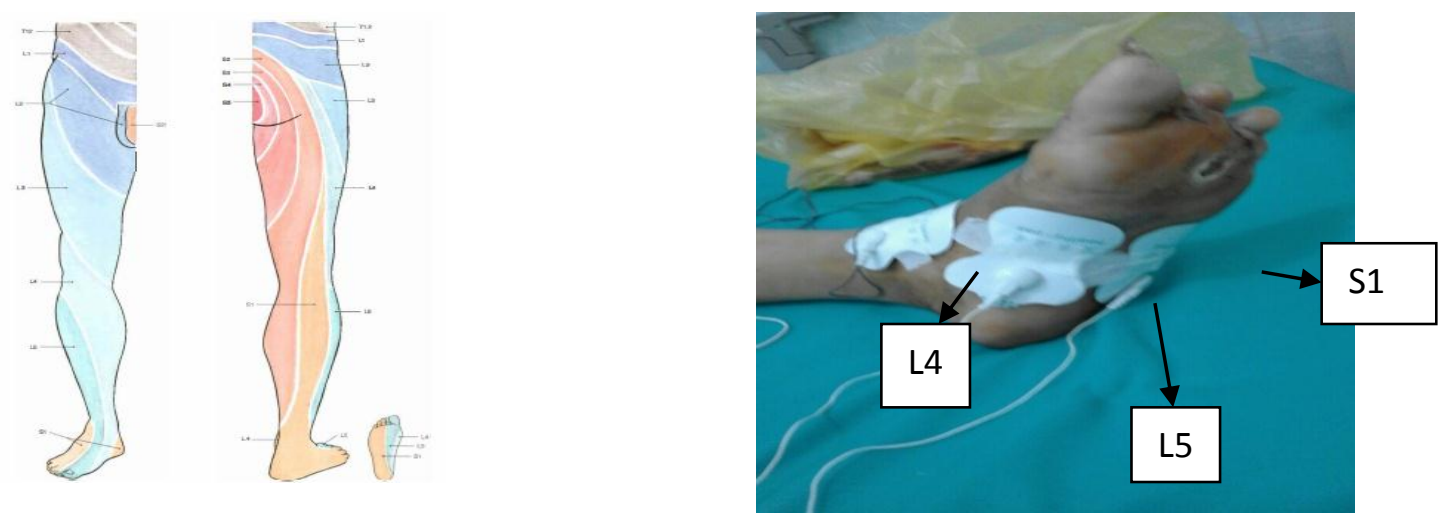

Gambar 1. Jalur Inervasi dan Letak Pemasangan Elektroda TENS

Ketika responden dilakukan perawatan luka dan diberikan TENS, responden mengaku merasakan sensasi geli di bagian kaki. Ini menunjukkan bahwa rangsangan listrik dapat dirasakan oleh saraf dibagian ekstremitas meskipun secara klinis responden mengalami neuropati diabetic. Tidak ada sensasi nyeri ataupun panas yang dilaporkan saat TENS diaktifkan. Kelebihan intervensi TENS saat dilakukan penelitian adalah mampu menurunkan skala nyeri hingga skala sedang, kondisi ini dapat menjadi pertimbangan perawat dan tim tenaga kesehatan lainnya untuk mengurangi pemberian obat 
anti nyeri dan digantikan dengan terapi komplementer berupa TENS. Besar harapan, dengan berkurangnya obat yang diberikan akan meringankan kerja dari ginjal dan organ-organ penting lain tubuh. Efek dari penurunan nyeri adalah munculnya rasa nyaman sehingga ansietas yang dialami responden ikut mengalami penurunan. Kekurangan dari alat TENS adalah pada kabel listrik yang cukup mengganggu saat dilakukan perawatan luka sehingga perawat harus berhati-hati dan cermat agar pemberian intervensi perawatan luka tetap diberikan dengan baik agar mencapai kebersihan secara maksimal.

Hasil perhitungan statistik menunjukkan bahwa nafas dalam juga mampu menurunkan ansietas pasien dengan nilai p 0.006 ( $p$ value $<0.05$ ). kondisi ini terjadi dikarenakan efek relaksasi nafas dalam yang mampu menurunkan kecepatan nadi, penurunan ketegangan otot, penurunan kecepatan metabolism, peningkatan kesadaran, perasaan damai, sejahtera dan kewaspadaan yang santai. Kondisi inilah yang membantu pasien mengalami penurunan nyeri ketika dilakukan perawatan luka kemudian diikuti juga oleh penurunan tingkat ansietas. Namun terdapat beberapa kendala saat penelitian dilakukan. Responden mengaku sulit mengalami relaksasi maksimal ketika dilakukan perawatan luka, pernyataan tersebut dipicu oleh posisi nyaman responden. Saat dilakukan perawatan luka, responden tidak bisa relaks secara maksimal karena sering kali kaki yang mengalami ulkus harus di ganjal dengan bantal untuk memaksimalkan perawatan luka, posisi ini akan menggangu posisi nyaman responden. Efek dari posisi yang tidak mendukung ini mengakibatkan relaksasi nafas dalam tidak bisa maksimal dalam menurunkan ansietas khususnya ansietas pada pasien DM dengan neuropati perifer yang dilakukan perawatan ulkus kaki.

Kedua intervensi yaitu TENS dan nafas dalam terbukti mampu menurunkan ansietas ketika dilakukan perawatan luka. Jika dilihat dari nilai delta maka akan terlihat bahwa TENS lebih banyak menurunkan skor nyeri dibandingkan dengan nafas dalam dimana TENS rata-rata menurunkan nyeri -1.0000 dan nafas dalam rata-rata menurunkan nyeri -0.5714. Nilai p-value delta ansietas adalah 0.034 ( $\mathrm{P}$ value $<$ 0.05), artinya beda gain ansietas antara kelompok yang mendapatkan intervensi TENS dan nafas dalam berkorelasi positif. Nafas dalam yang diberikan tidak lebih efektif dari TENS dikarenakan nyeri yang dirasakan responden ada yang mengalami nyeri skala sedang, sementara hasil kajian literatur menunjukkan bahwa nafas dalam kurang efektif bila diberikan pada pasien dengan skala nyeri sedang sehingga akan berpengaruh juga terhadap efektifitas penurunan ansietas. Hasil penelitian yang dilakukan oleh Pranata (2016) menunjukkan hasil bahwa TENS efektif menurunkan nyeri skala sedang ketika dilakukan perawatan luka, inilah mengapa TENS terbukti lebih baik menurunkan ansietas dibandingkan nafas dalam karena dengan menurunnya nyeri, dengan menurunnya nyeri ansietas juga ikut mengalami penurunan. 


\section{SIMPULAN DAN SARAN}

\section{Simpulan}

TENS dan nafas dalam secara statistik mampu menurunkan tingkat ansietas responden yang dilakukan perawatan luka kaki diabetic dengan neuropati perifer. Penurunan ansietas terjadi karena pengaruh dari penurunan nyeri yang dialami responden ketika dilakukan perawatan luka. Dilihat dari nilai delta, TENS lebih efektif menurunkan tingkat ansietas responden yang dilakukan perawatan luka kaki diabetic dengan neuropati perifer bila dibandingkan dengan nafas dalam.

\section{Saran}

Diharapkan perawat dapat mengaplikasikan intervensi TENS sebagai intervensi komplementer untuk menurunkan ansietas pada pasien yang dilakukan perawatan ulkus kaki diabetik.

\section{KEPUSTAKAAN}

Brunner and Suddarth. (2001). Keperawatan Medikal Bedah Edisi 8 Volume 2. Jakarta: Penerbit Buku Kedokteran EGC.

IDF. (2014). Panduan Global Untuk Diabetes Tipe 2. Retrieved from www.idf.org.communication@idf.org

Kristianto, H. (2010). Perbandingan Perawatan Luka Tekhnik Modern dan Konventional Terhadap Transforming Growth Factor Beta 1 dan Respon Nyeri Pada Luka Diabetes Melitus. Tesis dipublikasikan. Jakarta: FIK Program Magister Ilmu Keperawatan, 1.

Lemone, P \& Burke, K. (2008). No Title. Medical Surgical Nursing: Critical Thinking in Client Care 4 Ed. New Jersey: Pearson Education Inc.

Lewis, et al. (2005). No Title. Medical Surgical Nursing, Assessment and Management of Clinical Problem. New South Wales: Mosby Inc.

Potter, PA \& Perry, A. (2005). No Title. Fundamental Keperawatan Konsep, Proses, Dan Praktik, Volume 2, Edisi 4, EGC, Jakarta.

Pranata, S., Hs, K. H. N., \& Sujianto, U. (2016). The Effect Of Transcutaneous Electrical Nerve Stimulation ( Tens ) Towards Pain Level Of Patients With Diabetes Mellitus ( Dm ) With Peripheral Neuropathy In Diabetic Foot Ulcer Treatment In Yogyakarta General Hospital Indonesia Abstract :, 5(5), 76-80. http://doi.org/10.9790/1959-0505037680

Sharma, S., Majumder, K., Rao, J. K. D., Arya, V., Siwach, V., \& Gulia, S. (2015). Assessment of Relationship between Pain and Anxiety Following Dental Extraction - A Prospective Study, (July), 23-30.

Silbernagl, S. \& Lang, F. (2007). No Title. Teks Dan Atlas Berwarna Patofisiologi. Jakarta: EGC.

Soegondo, S. (2009). No Title. Farmakoterapi Pada Pengendalian Glikemia Diabetes Melitus Tipe 2. Dalam : Sudoyo, A.W., Ed. Buku Ajar Ilmu Penyakit Dalam Jilid III. Edisi Ke 4. Jakarta: Fakultas Kedokteran Universitas Indonesia.

Videbeck, S. . (2011). No Title.

Waspadji, S. (2009). No Title. Buku Ajar Penyakit Dalam: Komplikasi Kronik Diabetes Melitus, Mekanisme Terjadinya, Diagnosis Dan Strategi Pengelolaan, Jilid III, Edisi 4. Jakarta: FK UI. 